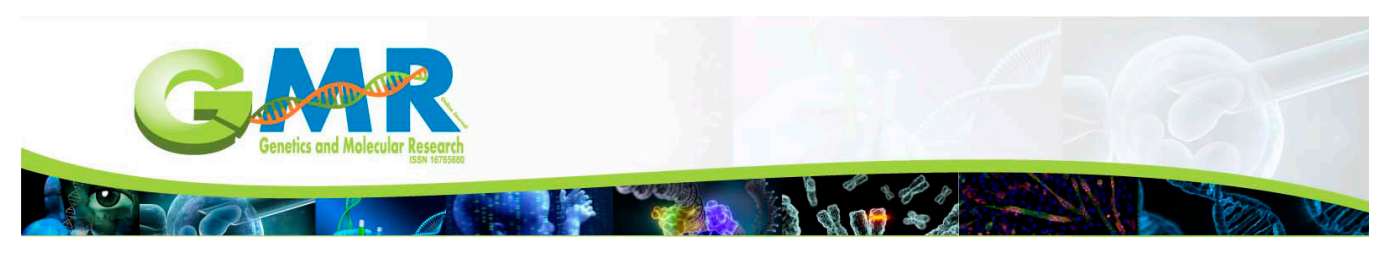

$\underline{\text { Retraction }}$

\title{
RETRACTION of articles with common plagiarism
}

\author{
Genet. Mol. Res. 15 (4): gmr1504005 \\ Published December 1, 2016 \\ DOI http://dx.doi.org/10.4238/gmr1504005
}

The GMR editorial staff was alerted about some articles that were found to be substantially equal. After a thorough investigation and contacting the authors, the Publisher and Editor of Genetics and Molecular Research decided to retract these articles in accordance with the recommendations of the Committee on Publication Ethics (COPE). The authors and their institutions were advised of this serious breach of ethics.

The abovementioned articles containing common plagiarism are:

GMR 4923

Ni ZY, Lin FO, Liu DF and Xiao J (2015). Decreased microRNA-143 expression and its tumor suppressive function in human oral squamous cell carcinoma. Genet. Mol. Res. 14: 6943-6952 http://dx.doi.org/10.4238/2015.June.26.2.

\section{Link to original paper}

GMR 5334

Bao Y, Peng L, Ma J, Liu K, et al. (2015). Decreased miR-134 expression and its tumor-suppressive function in human osteosarcoma. Genet. Mol. Res. 14: 16771-16781 http://dx.doi.org/10.4238/2015.December.14.4.

\section{Link to original paper}

GMR 6144

Wang ZT, Gong HY, Zheng F, Liu DJ, et al. (2015). Propofol suppresses proliferation and invasion of gastric cancer cells via downregulation of microRNA-221 expression. Genet. Mol. Res. 14: 8117-8124 http://dx.doi.org/10.4238/2015.July.17.20.

\section{Link to original paper}

Genetics and Molecular Research 15 (4): gmr1504005 
GMR 6700

Li QW, Zhou T, Wang F, Jiang M, et al. (2015). MicroRNA-215 functions as a tumor suppressor and directly targets ZEB2 in human pancreatic cancer. Genet. Mol. Res. 14: 16133-16145 http://dx.doi.org/10.4238/2015.December.8.2.

\author{
Link to original paper
}

GMR 7038

Zhang LQ, Sun SL, Li WY, Feng Z, et al. (2015). Decreased expression of tumor suppressive miR-874 and its clinical significance in human osteosarcoma. Genet. Mol. Res. 14: 18315-18324 http://dx.doi.org/10.4238/2015.December.23.19.

\title{
Link to original paper
}

These articles contain portions of the text that are similar to each other and to manuscripts that had already been published. All figures, along with their legends, are likely the same and/or modified from studies already published and from the abovementioned papers published by GMR.

The studies, from where the texts and figures were substantially copied, are:

- Gong Y, Ren J, Liu K and Tang LM (2015). Tumor suppressor role of miR-133a in gastric cancer by repressing IGF1R. World J. Gastroenterol. 21 (10): 2949-2958. DOI: 10.3748/wjg.v21.i10.2949

- Hou Y, Zhen J, Xu X, Zhen K, et al. (2015). miR-215 functions as a tumor suppressor and directly targets ZEB2 in human non-small lung cancer. Oncol. Lett. 10 (4): 1985-1992

- Liu X, Yan S, Pei C and Cui Y (2015). Decreased miR-132 function in human non-small non-small cell lung cancer. Mol. Med. Rep. 11 (5): 3601-3608. DOI: 10.3892/ mmr.2015.3222. 